\title{
Pair-Box (PAX8) protein-positive expression is associated with poor disease outcome in women with endometrial cancer
}

\author{
P Mhawech-Fauceglia*,I,5, D Wang², D Samrao', H Godoy ${ }^{3}$, T Pejovic ${ }^{4}$, S Liu' ${ }^{2}$ and S Lele ${ }^{3}$ \\ 'Department of Pathology at Roswell Park Cancer Institute, Buffalo, NY, USA; ${ }^{2}$ Department of Biostatistics at Roswell Park Cancer Institute, Buffalo, \\ NY, USA; ${ }^{3}$ Department of Gynecology-Oncology at Roswell Park Cancer Institute, Buffalo, NY, USA; ${ }^{4}$ Division of Gynecologic Oncology at Oregon \\ Health \& Science University and the Knight Cancer Institute, Portland, OR, USA
}

BACKGROUND: The Pax8 transcription factor genes have a role in cell differentiation and cell growth, and silencing of Pax8 in cell cultures results in cell death. The aims of this study were to determine the expression and correlation of Pax 8 protein with several clinicopathological variables in patients with endometrial cancer.

METHODS: The following clinical parameters from 229 patients were used for correlation with Pax8 expression; age, histological subtype, myometrial depth of invasion, lymphovascular invasion (LVI), the International Federation of Gynecology and Obstetrics grade, lymph nodes status, and disease status.

RESULTS: A positive association of $\mathrm{Pax}^{+}$expression was found with high tumour grade $(P=0.002), \mathrm{LVI}+(P=0.0 \mathrm{I} 86)$, and type $\|$ tumour subtype $(P<0.000 I)$ in univariate analysis. Survival analysis showed an association of Pax8 and 5 -year overall survival probability $(P=0.01486), 80.04 \%$ for patients with $P a x 8^{-}$and $55.59 \%$ for patients with $P a x 8^{+}$. There was also an association of Pax8 and 5 -year disease-free survival probability $(P=0.02028), 72.12 \%$ for patients with $P a x 8^{-}$vs $49.88 \%$ for patients with $P a x 8^{+}$. Finally, an association of $\mathrm{Pax} 8^{+}$and shorter recurrence-free survival was also found $(P=0.00203)$, with $74.36 \%$ for $P a \times 8^{-}$and 52.11\% for $\mathrm{Pax} 8^{+}$.

CONCLUSION: Overexpression of Pax8 protein by endometrial cancer is associated with poor disease outcomes. Inhibition of Pax8 may be a very attractive targeted therapy for selective patients.

British Journal of Cancer (2012) 107, 370-374. doi:I0.1038/bjc.2012.24I www.bjcancer.com

Published online 29 May 2012

(c) 2012 Cancer Research UK

Keywords: Pax8; endometrial cancer; immunoexpression; disease outcome; prognostic biomarker

Endometrial carcinoma (EC) is the most common gynaecologic malignancy in the United States and it is the fifth leading cause of cancer-related death in women (Jemal et al, 2009). Endometrioid adenocarcinomas (EAC) account for more than $80 \%$ of cases and tend to present as low-grade, early-stage tumours with favourable outcomes. Meanwhile, uterine serous carcinomas (USC) represent a minority $(3-10 \%)$ of total endometrial cancer cases. They are usually high-grade tumours with deep myometrial invasion (MI), lymphovascular invasion (LVI), and a more aggressive clinical course (Part, 2004; Benito et al, 2009; Kitchener and Trimble, 2009). Despite the validation of the prognostic value of a number of biomarkers in EC, clinicopathological factors such as tumour grade, stage, histological subtypes, LVI, and depth of MI are still considered as the most reliable prognostic parameters. High-grade tumour, advanced stage disease, presence of LVI, deep MI (outer third) and type II (USC and clear cell subtypes) endometrial adenocarcinoma constitute a high-risk group for recurrence and aggressive outcome in comparison to a low-risk group defined by low tumour grade, tumour confined to uterine corpus at

* Correspondence: Dr P Mhawech-Fauceglia;

E-mail: pfauceglia@hotmail.com

${ }^{5}$ Current address: Department of Pathology, University of Southern California, I200N. State Street, Room 7Al16, Los Angeles, CA 90033-5000, USA

Received 13 March 2012; revised 3 May 2012; accepted 4 May 2012; published online 29 May 2012 presentation, absence of LVI, superficial MI (inner third), and type I (EAC and mucinous subtypes) endometrial adenocarcinoma (Figge et al, 1983; Keys et al, 2004; Part, 2004).

Pax8 is a member of the pair-box (PAX) family of transcription factor genes. It is important in the organogenesis of the thyroid, kidney, and mullerian tracts (Poleev et al, 1990; Mittag et al, 2007). Interestingly, Pax8 expression was found to be restricted to secretory cells of the fallopian tube epithelium, which most recently has been suggested as the cell of origin for serous ovarian carcinomas (Bowen et al, 2007). Otherwise, the interest in Pax8 in the reproductive tract has mainly focused on its use as a marker to distinguish carcinoma of gynaecologic origin $v s$ carcinoma from other organs and from mesothelioma (Nonaka et al, 2008; Laury et al, 2010, 2011). The potential role of Pax8 in the endometrium has been rarely explored (Brunner et al, 2011). In this study, our aim is to define whether the expression of Pax8 protein in formalin-fixed samples from 229 patients correlated with disease outcome, such as recurrence rate, time to recurrence, and survival as well as with clinical-pathological factors such as tumour subtype, tumour grade and stage, LVI, depth of MI, and lymph node status.

\section{MATERIALS AND METHODS}

\section{Patient population}

After obtaining Institutional Review Board (IRB) approval, pathology archives were searched for cases of endometrial 
malignant neoplasms from January 2000 to December 2010. A chart review was conducted with extraction of clinical information, including the patients' age at the time of diagnosis, the surgical stage, the post-operative therapy, the recurrence-free survival (RFS), the disease-free survival (DFS), the site of recurrence, the cause and the time of death. All patients underwent a complete surgical staging procedure, including a total abdominal hysterectomy with bilateral salpingo-oophorectomy, pelving washing, with or without pelvic and para-aortic lymph node dissection depending on the tumour grade and the tumour subtypes. Patients were treated according to the National Comprehensive Cancer Network guidelines (www.cancer.gov).

\section{Histological evaluation}

Tumour grade was assessed using the International Federation of Gynecology and Obstetrics (FIGO) system and by nuclear grading. The FIGO grading was determined as follows; tumours with $<5 \%$ solid areas were grade 1 (G1), tumours with $5-50 \%$ solid areas were grade $2(\mathrm{G} 2)$ and tumours with $>50 \%$ solid areas were grade 3 (G3). Tumours nuclear grade was determined by the variation in nuclear size and shape, chromatin distribution, and size of the nucleoli. Tumour stage was assigned based on 1988 FIGO surgical staging guidelines (FIGO, 1989). All slides were examined by an expert gynaecologic pathologist for confirmation of the tumour type, tumour grade, depth of MI, presence of LVI and positive lymph nodes.

Four $-\mu \mathrm{m}$ sections from formalin-fixed, paraffin-embedded tissues were processed for immunohistochemistry (IHC). Endogenous peroxidase was blocked with $0.3 \%$ hydrogen peroxidase for $5 \mathrm{~min}$. Antigen retrieval was carried out in high citrate buffer for $3 \mathrm{~min}$ in a steam-cooker. Then, sections were incubated overnight with Pax8 antibody (monoclonal antibody, 1:400 dilutions; Biocare lab, San Francisco, CA, USA). A subsequent reaction was performed with the biotin-free HRP enzyme-labelled polymer of the Envision plus detection system (Dakocytomation, Carpinteria, CA, USA). Diaminobenzidine complex was used as the chromogen. Normal kidney and thyroid tissue were used as positive controls. In negative controls, a normal goat serum was used instead of the primary antibody resulting in a lack of detectable staining. Two pathologists (PMF and DS) reviewed the IHC slides on a double-headed microscope; only positive nuclear staining was considered positive and the staining intensity was interpreted as negative, weak, moderate, or strong. Both pathologists were unaware of the primary diagnosis. Only the staining intensity was taken into consideration for primary statistical analysis and it was divided into two groups; negative/weak was considered as negative (group I) and moderate/strong was considered as positive (group II).

\section{Statistical analyses}

Statistical analyses were performed by R (http://www.r-project.org/). The clinical parameters used for modelling were age, tumour size, histological subtype, myometrial depth of invasion, LVI, FIGO grade, lymph nodes positive, recurrence, status, recurrence time, and survival time. Univariate and multivariate analysis was performed. To test the association between the biomarker and the clinical parameters, Fisher's exact test was performed for categorical parameters, and a logistic regression model was used for continuous parameters. For survival analysis, overall survival (OS) was censored at the time of last follow-up; events were death due to any cause. Disease-free survival (DFS) was censored at the time of last follow-up if disease progression did not occur; events were death due to any cause, disease relapse, and progression. Recurrence-free survival was censored at the time of last follow-up if the recurrence did not occur; events were death due to any cause and recurrence. The Kaplan-Meier method with log-rank test was used to calculate the cumulative survival time and check the OS, RFS, and DFS difference between the two different Pax8 groups. All reported $P$-values are two-sided. $P$-value was considered significant if $P<0.05$.

\section{RESULTS}

The clinical and pathological features of 229 patients with endometrial adenocarcinoma are summarised in Table 1. The patients' ages ranged from 29 to 97 years (median 65). Overall, $72 \%$ of cases were type I and $28 \%$ were type II subtype. In total, $42 \%$ of cases were FIGO G1, $20 \%$ G2, and $38 \%$ G3. As for tumour stage, $64 \%$ of cases were FIGO stage I, $14 \%$ stage II, $15 \%$ stage III, and $7 \%$ stage IV. Tumour size was considered as zero when no gross tumour was identified. In all, $65.5 \%$ of patients had lymph

Table I Clinical and pathological features of 229 patients with endometrial cancer

\begin{tabular}{|c|c|c|}
\hline & No. of cases & $\%$ \\
\hline No. of evaluable patients & 229 & \\
\hline $\begin{array}{l}\text { Age (years) } \\
\text { Median } \\
\text { Range }\end{array}$ & $\begin{array}{c}65 \\
(29,97)\end{array}$ & \\
\hline $\begin{array}{l}\text { Myometrial invasion (\%) } \\
\text { Median } \\
\text { Range }\end{array}$ & $\begin{array}{c}30 \\
(0,100)\end{array}$ & \\
\hline $\begin{array}{l}\text { Tumour size }(\mathrm{cm}) \\
\text { Median } \\
\text { Range }\end{array}$ & $\begin{array}{c}4 \\
(0,33)\end{array}$ & \\
\hline $\begin{array}{l}\text { Tumour subtype } \\
\text { Type ॥ } \\
\text { Type I }\end{array}$ & $\begin{array}{r}64 \\
165\end{array}$ & $\begin{array}{l}28 \\
72\end{array}$ \\
\hline $\begin{array}{c}\text { Grade FIGO } \\
1 \\
2 \\
3\end{array}$ & $\begin{array}{l}96 \\
46 \\
87\end{array}$ & $\begin{array}{l}42 \\
20 \\
38\end{array}$ \\
\hline $\begin{array}{l}\text { Grade nuclear } \\
\quad 1 \\
2 \\
3\end{array}$ & $\begin{array}{l}80 \\
59 \\
90\end{array}$ & $\begin{array}{l}35 \\
26 \\
39\end{array}$ \\
\hline $\begin{array}{l}\text { Recurrence } \\
\text { No } \\
\text { Persistent } \\
\text { Progression } \\
\text { Yes }\end{array}$ & $\begin{array}{r}177 \\
10 \\
3 \\
39\end{array}$ & $\begin{array}{r}77 \\
4 \\
1 \\
17\end{array}$ \\
\hline $\begin{array}{l}\text { Pax8 immunoexpression } \\
\text { Negative } \\
\text { Positive }\end{array}$ & $\begin{array}{r}158 \\
71\end{array}$ & $\begin{array}{l}69 \\
31\end{array}$ \\
\hline $\begin{array}{l}\text { LVI } \\
\text { No } \\
\text { Yes }\end{array}$ & $\begin{array}{r}161 \\
68\end{array}$ & $\begin{array}{l}70 \\
30\end{array}$ \\
\hline $\begin{array}{l}\text { Tumour stage } \\
\text { I } \\
\| \\
\text { III } \\
\text { IV }\end{array}$ & $\begin{array}{r}146 \\
31 \\
35 \\
17\end{array}$ & $\begin{array}{r}64 \\
14 \\
15 \\
7\end{array}$ \\
\hline $\begin{array}{l}\text { Lymph node positive } \\
\text { Not applicable } \\
\text { No } \\
\text { Yes }\end{array}$ & $\begin{array}{r}79 \\
118 \\
32\end{array}$ & $\begin{array}{l}34 \\
52 \\
14\end{array}$ \\
\hline $\begin{array}{l}\text { Disease status } \\
\text { Alive with no evidence of disease } \\
\text { Alive with evidence of disease } \\
\text { Dead of unkown cause } \\
\text { Dead no evidence of disease } \\
\text { Dead of disease } \\
\text { Dead with evidence of disease } \\
\text { Lost for follow-up }\end{array}$ & $\begin{array}{r}159 \\
19 \\
1 \\
13 \\
32 \\
4 \\
1\end{array}$ & $\begin{array}{r}69 \\
8 \\
0 \\
6 \\
14 \\
2 \\
0\end{array}$ \\
\hline
\end{tabular}


nodes dissection. Of these, $21.3 \%$ patients had positive lymph nodes and $78.6 \%$ had negative lymph nodes.

Univariate analysis of the distribution of clinical factors in relation to dichotomous status of Pax8 expression is illustrated in Table 2. There was a positive association between $\mathrm{Pax} 8^{+}$and high tumour grade $(P=0.002)$, presence of LVI $(P<0.019)$, and type II tumour subtype $(P<0.0001)$. Serous and clear cell carcinomas as well as carcinosarcoma were more likely to express Pax8 than endometrioid adenocarcinomas. Pax8 expression is negatively associated with OS $(P=0.0097)$ and DFS $(P=0.019)$. However, these significant results were not found in multivariate analysis (data not shown).

Kaplan-Meier survival analysis was conducted. There was an association of Pax8 with OS $(P=0.01486)$ with 5-year OS probability of $80.04 \%$ for patients with Pax 8 - and $55.9 \%$ for patients with $\mathrm{Pax} 8^{+}$(Figure 1). There was also an association of Pax8 and DFS probability $(P=0.02028)$ with 5-year DFS probability of $72.12 \%$ for patients with Pax $8-v s 49.88 \%$ for patients with $\mathrm{Pax} 8^{+}$expression (Figure 2). Finally an association of $\mathrm{Pax} 8^{+}$

Table 2 Univariate analysis of the association of Pax8 and the clinicopathological variate

\begin{tabular}{lcccc}
\hline & $\begin{array}{c}\text { Pax8 } \\
\text { negative }\end{array}$ & $\begin{array}{c}\text { Pax8 } \\
\text { positive }\end{array}$ & P-value & $\begin{array}{c}\text { Odds } \\
\text { ratio }\end{array}$ \\
\hline Age & $63.04^{\mathrm{a}}$ & 69.58 & 0.0003 & 1.045435 \\
Tumour size & 4.77 & 4.29 & 0.3674 & 0.962615 \\
Myometrial invasion & 40.95 & 39.3 & 0.7384 & 0.998615 \\
Grade FIGO & & & & \\
$\quad$ I & & & 0.0024 & 2.168619 \\
2 & $74(46.84)^{\mathrm{b}}$ & $22(30.99)$ & & \\
3 & $36(22.78)$ & $10(14.08)$ & & \\
& $48(30.38)$ & $39(54.93)$ & &
\end{tabular}

$\begin{array}{cll}\text { Grade nuclear } & & \\ 1 & 66(41.77) & 14(19.72) \\ 2 & 42(26.58) & 17(23.94) \\ 3 & 50(31.65) & 40(56.34)\end{array}$

$\begin{array}{ccc}\text { Tumour stage } & & \\ \text { I } & 105(66.46) & 41(57.75) \\ \text { II } & 17(10.76) & 14(19.72) \\ \text { III } & 24(15.19) & 11(15.49) \\ \text { IV } & 12(7.59) & 5(7.04)\end{array}$

\begin{tabular}{|c|c|c|c|c|}
\hline $\begin{array}{l}\text { Tumour subtype } \\
\text { Type II } \\
\text { Type I }\end{array}$ & $\begin{array}{r}30(18.99) \\
128(81.01)\end{array}$ & $\begin{array}{l}34(47.89) \\
37(52.11)\end{array}$ & $<0.0001$ & 0.256816 \\
\hline $\begin{array}{l}\text { Recurrence } \\
\text { No } \\
\text { Yes }\end{array}$ & $\begin{array}{r}127(85.81) \\
21(14.19)\end{array}$ & $\begin{array}{l}50(73.53) \\
18(26.47)\end{array}$ & 0.0363 & 2.168619 \\
\hline $\begin{array}{l}\text { LVI } \\
\text { No } \\
\text { Yes }\end{array}$ & $\begin{array}{r}119(75.32) \\
39(24.68)\end{array}$ & $\begin{array}{l}42(59.15) \\
29(40.85)\end{array}$ & 0.0186 & 2.099539 \\
\hline $\begin{array}{l}\text { Lymph node } \\
\text { No } \\
\text { Yes }\end{array}$ & $\begin{array}{l}72(79.12) \\
19(20.88)\end{array}$ & $\begin{array}{l}46(77.97) \\
13(22.03)\end{array}$ & 1.00 & 1.070446 \\
\hline $\begin{array}{l}\text { Disease status } \\
\text { Alive } \\
\text { Dead }\end{array}$ & $\begin{array}{r}|3|(82.9 \mid) \\
27(17.09)\end{array}$ & $\begin{array}{l}47(67.14) \\
23(32.86)\end{array}$ & 0.0096 & 2.3644 \\
\hline $\begin{array}{l}\text { Disease status } \\
\text { Alive with no evidence } \\
\text { of disease } \\
\text { Others }\end{array}$ & $\begin{array}{l}118(74.68) \\
40(25.32)\end{array}$ & $\begin{array}{l}41(58.57) \\
29(41.43)\end{array}$ & 0.0189 & 2.07943 \\
\hline
\end{tabular}

Continuous variables are tested by logistic regression and categorical variables are tested by the Fisher test. ${ }^{a}$ Mean. ${ }^{b}$ Count (\%). and shorter RFS was also seen $(P=0.00203)$, with $74.36 \%$ for $\mathrm{Pax} 8{ }^{-}$patients and $52.11 \%$ for $\mathrm{Pax}^{+}$patients (Figure 3 ).

\section{DISCUSSION}

The Pax 8 is located at the $2 \mathrm{q} 13$ chromosome band. It is a member of the pair-box family of genes that are required for the formation of several tissues from all germ layers in the mammalian embryo (Poleev et al, 1990; Mittag et al, 2007). Particularly, Pax8 gene is

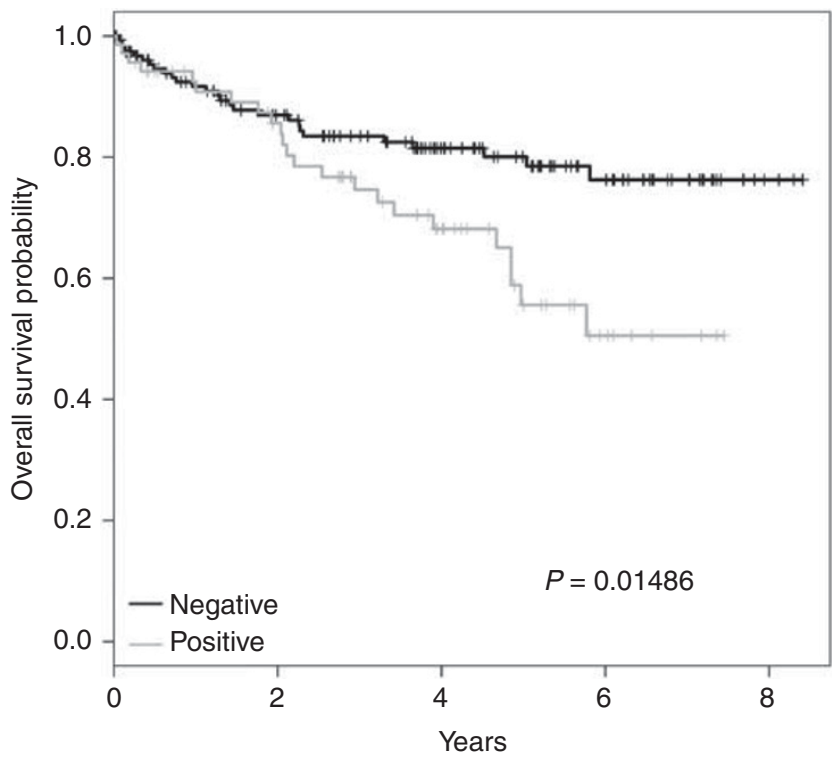

Figure I Kaplan-Meier survival analysis revealed the association of Pax 8 with overall survival $(P=0.01486)$. The black curve is for $\mathrm{Pax} 8^{-}$patients and the grey curve is for $\mathrm{Pax} 8^{+}$patients. The 5 -year overall survival probabilities for the $\mathrm{Pax}^{-}$and $\mathrm{Pax}^{+}$patients were 80.04 and $55.59 \%$, respectively.

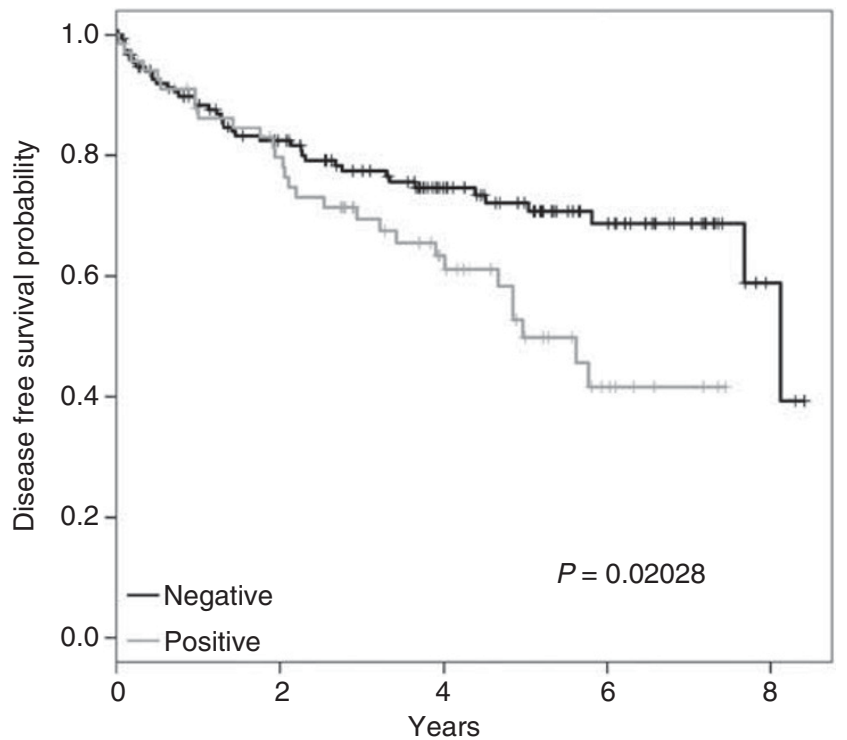

Figure 2 Kaplan-Meier survival analysis revealed the association of Pax8 with DFS probability $(P=0.02028)$. The black curve is for $P a \times 8^{-}$patients and the grey curve is for $\mathrm{Pax}^{+}$patients. Five-year DFS probability of $72.12 \%$ for patients with $\mathrm{Pax}^{-}$vs $49.88 \%$ for patients with $\mathrm{Pax}^{+}$ expression. 


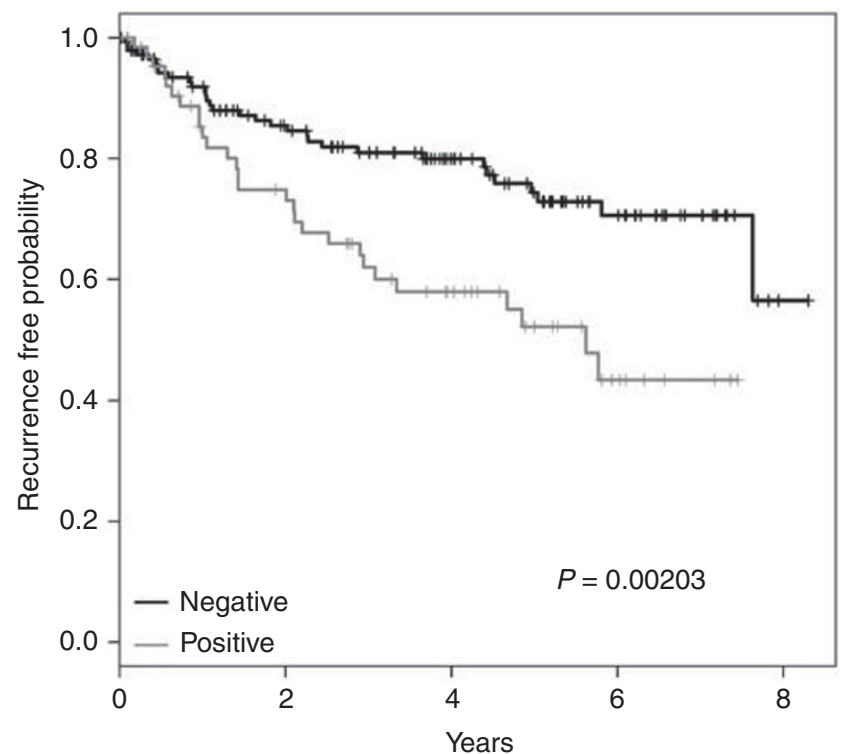

Figure 3 Kaplan-Meier survival analysis revealed the association of Pax8 with recurrence-free probability $(P=0.00203)$. The black curve is for $\mathrm{Pax} 8^{-}$patients and the grey curve is for $\mathrm{Pax}^{+}$patients. The 5 -year recurrence-free probability for the $\mathrm{Pa} \times 8^{-}$and $\mathrm{Pa} \times 8^{+}$patients are 74.36 and $52.11 \%$, respectively.

essential for the organogenesis of the mullerian system, thyroid, and kidney. The biological significance of Pax8 protein expression in cancer is unknown, but recent studies suggest a possible role of Pax8 in tumourigenesis (Castro et al, 2006; Cheung et al, 2011). In a previous study of human endometrial cancer samples, we found an upregulation of $\operatorname{Pax} 8$ gene in advanced stage USC $v s$ early stages USC (fold-change $=1.44$ ) and an upregulation of Pax8 in USC with bad outcome vs USC with good outcomes (fold-change $=1.72$ ), although statistical significance was not reached $(P>0.05)$ possibly due to our small sample size $(n=5)$ (Mhawech-Fauceglia et al, $2010,2011)$. In this study, we sought to identify the expression and prognostic value of Pax8 protein expression in a large series of human endometrial cancer cases.

On univariate analysis, Pax8 protein-positive expression was associated with clinical and pathological predictive factors of poor outcome, such as high tumour grade, histological subtypes II, and

\section{REFERENCES}

Benito V, Lubrano A, Arencibia O, Alvarez EE, Laureano Leon, Medina N, Falcon JM, Falcon O (2009) Pure papillary serous tumors of the endometrium: a clinicopathological analysis of 61 cases from a single institution. Int J Gynecol Cancer 19: 1364-1369

Bowen NJ, Logani S, Dickerson EB, Kapa LB, Akhtar M, Benigno BB, McDonald JF (2007) Emerging roles for PAX8 in ovarian cancer and endosalpingeal development. Gynecol Oncol 104: 331-337

Brunner AH, Riss P, Heinze G, Meltzow E, Brustmann H (2011) Immunoexpression of PAX8 in endometrial cancer: relation to highgrade carcinoma and p53. Int J Gynecol Pathol 30: 569-575

Castro P, Rebocho AP, Soares RJ, Magalhães J, Roque L, Trovisco V, Vieira de Castro I, Cardoso-de-Oliveira M, Fonseca E, Soares P, Sobrinho-Simões M (2006) PAX8-PPAR gamma rearrangement is frequently detected in the follicular variant of papillary thyroid carcinoma. J Clin Endocrinol Metab 91: 213-220

Cheung HW, Cowley GS, Weir BA, Boehm JS, Rusin S, Scott JA, East A, Ali LD, Lizotte PH, Wong TC, Jiang G, Hsiao J, Mermel CH, Getz G, Barretina J, Gopal S, Tamayo P, Gould J, Tsherniak A, Stransky N, Luo B, Ren Y, Drapkin R, Bhatia SN, Mesirov JP, Garraway LA, Meyerson M, Lander ES, Root DE, Hahn WC (2011) Systematic investigation of genetic vulnerabilities across cancer cell lines reveals lineage-specific dependencies in ovarian cancer. Proc Natl Acad Sci USA 108: 12372-12377 presence of LVI. The association of Pax8 with tumour grade, and histologic type was seen in a previous study (Brunner et al, 2011). We also found that patients with tumours expressing Pax8 were more likely to die form disease. The 5-year OS probability for patients with $\mathrm{Pax} 8^{-}$was better than those with $\mathrm{Pax}^{+}{ }^{+}(80.04$ vs $55.9 \%)$. Also, patients with Pax $8^{-}$have better 5-year DFS $(72.12 \%$ for patients $v s$ 49.88\%) and better 5-year RFS (74.36\% vs $52.11 \%$ ) in comparison with those patients with $\mathrm{Pax} 8^{+}$tumours. These findings validate results of our prior study and provide evidence that overexpression of Pax 8 protein could be a potential biomarker for poor outcome in patients with endometrial cancer.

Recently, Hahn and group showed an overexpression of Pax8 in numerous cancer cell lines, including ovarian and endometrial cancer (Cheung et al, 2011). In addition, when untested shRNAs against Pax8 were introduced to ovarian, kidney, and endometrial cancer cell lines, a drop in cell viability in cells that overexpressed Pax8 was noted, suggesting that inhibition of Pax8 activity could have a substantial impact on cancer treatment. Owing to high expression of Pax 8 by type II tumours, which can be resistant to traditional chemotherapy, tailored targeted therapy to silence Pax8 could be a promising therapeutic option for these cases. Mechanistic studies are being conducted in our laboratory to define the role of Pax8 in cell culture.

In summary, our results indicate that endometrial cancer patients with tumours expressing $\mathrm{Pax} 8^{+}$have worse clinical outcomes compared with those with $\mathrm{Pax} 8^{-}$. Pax $8^{+}$expression pattern is found to be negatively associated with 5-year OS, 5 -year DFS, and 5-year RFS probabilities. These findings support the potential clinical utility of incorporating Pax8 IHC in the evaluation of endometrial cancer patients in order to identify those who are at higher risk of early recurrence. Silencing Pax 8 could be the target of a new generation of therapeutic agents for selected patients.

\section{ACKNOWLEDGEMENTS}

We thank Dr Kunle Odunsi for his continuous scientific advice. We also would like to thank Dr Faith Ough for reviewing the manuscript.

\section{Conflict of interest}

The authors declare no conflict of interest.

FIGO (1989) Announcements, stages-1988 revision. Gynecol Oncol 35: 125

Figge DC, Otto PM, Tamimi HK, Greer BE (1983) Treatment variables in the management of endometrial cancer. Am J Obstet Gynecol 146: $495-500$

Jemal A, Siegel R, Ward E, Hao Y, Xu J, Thun MJ (2009) Cancer statistics, 2009. CA Cancer J Clin 59: 225-249

Keys HM, Roberts JA, Brunetto VL (2004) A phase III trial of surgery with or without adjunctive external pelvic radiation therapy in intermediate risk endometrial adenocarcinoma: a Gynecologic Oncology Group study. Gynecol Oncol 92: 744-751

Kitchener HC, Trimble EL (2009) Endometrial cancer state of the science meeting. Int J Gynecol Cancer 19: 134-140

Laury AR, Hornick JL, Perets R, Krane JF, Corson J, Drapkin R, Hirsch MS (2010) PAX8 reliably distinguishes ovarian serous tumors from malignant mesothelioma. Am J Surg Pathol 34: 627-635

Laury AR, Peters R, Piao H, Krane JF, Barletta JA, French C Chirieac LR, Lis R, Loda M, Hornick JL, Drapkin R, Hirsch MS (2011) A comprehensive analysis of PAX8 expression in human epithelial tumors. Am J Surg Pathol 35: 816-826

Mhawech-Fauceglia P, Wang D, Kesterson J, Clark K, Monhollen L, Odunsi K, Lele S, Liu S (2010) Microarray analysis reveals distinct gene 
expression profiles among different tumor histology, stage and disease outcomes in endometrial adenocarcinoma. PLoS One 5: e15415

Mhawech-Fauceglia P, Wang D, Wang D, Syriac S, Kesterson J, Clark K, Frederick P, Lele S, Liu S (2011) Gene expression profiles in stage I uterine serous carcinoma in comparison to grade 3 and grade 1 stage I endometrioid adenocarcinoma. PLOS One 6: e18066

Mittag J, Winterhager E, Bauer K, Grummer R (2007) Congenital hypothyroid female pax8-deficient mice are infertile despite thyroid hormone replacment therapy. Endocrinology 148: 719-725
Nonaka D, Chiriboga L, Soslow RA (2008) Expression of Pax8 as a useful marker in distinguishing ovarian carcinomas from mammary carcinomas. Am J Surg Pathol 32: 1566-1571

Part J (2004) Prognostic parameters of endometrial carcinoma. Hum Pathol 35: 649-662

Poleev A, Fickenscher H, Mundlos S, Winterpacht A, Zabel B, Fidler A, Gruss P, Plachov D (1990) PAX8, a human paired box gene: isolation and expression in developing thyroid, kidney and Wilm's tumors. Development 116: 611-623

This work is published under the standard license to publish agreement. After 12 months the work will become freely available and the license terms will switch to a Creative Commons Attribution-NonCommercial-Share Alike 3.0 Unported License. 